\title{
ASEAN-US ECONOMIC COOPERATION AND ITS IMPACTS ON REGIONAL SECURITY AND DEVELOPMENT
}

\author{
Le Thi Phuong Loan'; Vo Thi Giang ${ }^{2}$ \\ ${ }^{1}$ Lecturer at Faculty of International Studies, University of Foreign Language Studies, The University of \\ Danang; Ph.D. candidate at University of Social Sciences and Humanities, Viet Nam National University \\ - Ha Noi, Viet Nam. \\ ${ }^{2}$ MSc Student at Graduate School of Asia Pacific Studies, Ritsumeikan Asia Pacific University, Japan. \\ DOI: 10.46609/IJSSER.2020.v05i10.020 URL: https://doi.org/10.46609/IJSSER.2020.v05i10.020
}

\begin{abstract}
This paper examines the economic cooperation dimensions in ASEAN-US relations and evaluates their impacts on regional security and development. ASEAN is an emerging economic base and one of the major trading and investment partners of the U.S. while the U.S. is a potential market for ASEAN in terms of exports. It is found that economics is used by both sides as an effective means to get deep engagement in the relations and regional policy-making system. The data in the paper captures the 2 sides' strategic interests in the region through economic collaboration. Broadly, analyses in the paper indicate that the economic gains maximized from the ASEAN-US cooperation through initiatives and projects aimed at preventing China's deep footprint and its presence in the region. Additionally, the increasingly intensive ASEAN-US economic cooperation is to balance Indian power and other great powers, specifically Japan and Australia - the 2 remaining countries in the so-called Quad, approaching the region with their ambitions.
\end{abstract}

Keywords: ASEAN-US relations, economic cooperation; regional development; regional security; Southeast Asia.

\section{Rationale}

The Association of Southeast Asian Nations (ASEAN) was established in 1967 by 5 founding fathers including Thailand, Malaysia, Singapore, Indonesia, and the Philippines. Since then, ASEAN has considered cooperation as the first key point in the development process of grouping over Southeast Asia. As the gateway connecting South Asia and Northeast Asia, Southeast Asia 


\section{International Journal of Social Science and Economic Research}

ISSN: $2455-8834$

Volume:05, Issue:10 "October 2020"

with ASEAN bloc has grown dynamically, playing a crucial role in linkages among countries within the region on interdisciplinary cooperation.

ASEAN has been successful in establishing one common community - the ASEAN Community at the end of 2015, a solid foundation for intra-regional collaboration. With the realized implementation of ASEAN Economic Community (AEC), making ASEAN the world's thirdlargest labor force of more than 622 million people and a market of US\$ 2.6 trillion, ASEAN then has effective tools to promote its economic cooperation beyond the region. The tremendous economic progress over recent decades has triggered the $3^{\text {rd }}$ position of ASEAN in terms of the fastest-growing economy in Asia (after China and India), and the world's $5^{\text {th }}$ largest economic community (as of 2017). Making the most of $60 \%$ of ASEAN's population who are under 35 , and $43 \%$ out of that is under the age of 24 , ASEAN is expected to rocket its economy to become the world's $4^{\text {th }}$ largest economy by 2050 , overtaking the position of the European Union and Japan (ASEAN, 2018). Figure 1 shows ASEAN's significant growth since the late $20^{\text {th }}$ century, and this growth keeps increasing in later years.

\section{Figure 1: ASEAN's economic journey since inception (GDP at current prices), US\$ billions}

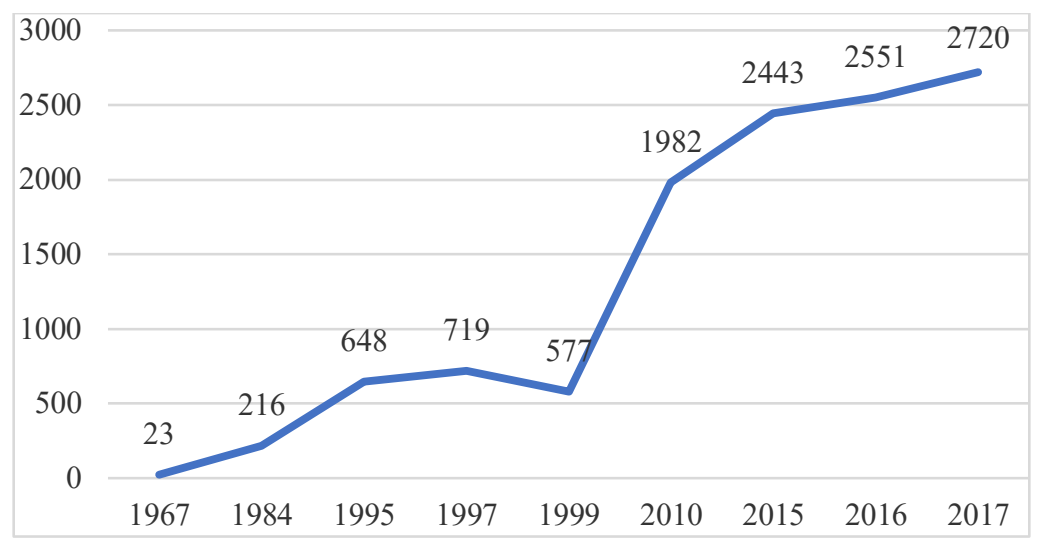

Source: David, W. (2018)

Rapid economic growth along with the increasingly important location strategically has made ASEAN a far much potential and promising market for the U.S. The AEC establishment enables ASEAN to become the $4^{\text {th }}$ largest trading partner and export market of the U.S. (as of 2016). Both sides started the bilateral relations with each other in 1977 when the first ASEAN-U.S. dialogue took place in Manila, making the U.S. an ASEAN dialogue partner, and the relations have changed significantly since then as both sides realized mutual interest in wider engagement. The ASEAN-U.S. relations have developed and elevated over time. In the post-Cold War period, the U.S. started bilateral relations tightly with ASEAN member states, mainly focusing on 


\section{International Journal of Social Science and Economic Research}

ISSN: 2455-8834

Volume:05, Issue:10 "October 2020"

economic growth since the Trade and Investment Framework Arrangement (TIFA) was signed in 2006 to provide further structure for cooperation on economic matters. The U.S. until now is the last country in ASEAN's 10 dialogue external partners that do not have the legally binding Free Trade Agreement (FTA) with ASEAN (Calaguian-Cruz, 2011), hence TIFA is considered as a non-binding document with joint activities implemented by both ASEAN and the U.S. to promote and enhance trade and investment. Another important achievement marking a milestone in ASEAN-US relations was the U.S. became the very first non-ASEAN country to assign a resident ambassador to ASEAN before signing the Treaty of Amity and Cooperation (TAC) in 2009, and set up its permanent mission in 2010, making a vow to stand side-by-side and creates favorable conditions to enhance mutual interests economically.

A variety of initiatives and programs have been launched and a host of policies have also been adjusted in the legislative of the U.S. and ASEAN, leading to significant changes in economic relations. Former U.S. Presidents paid much attention to multilateral relations, which means economic relations with ASEAN was one of the top priorities in the U.S. foreign policies. However, the leadership of Trump in his first-half stint focused roughly on purely bilateral relations and took unprecedented actions. Owing to those changes, the ASEAN-U.S. economic relations has changed in response. The increasingly important role of ASEAN in Asia - Pacific has been obvious, so its economic cooperation with the U.S. has profound impacts on regional security and development.

How have the U.S. and ASEAN adjusted their foreign policies to develop the economic cooperation relations between the two sides as the regional situation has been too volatile and has many factors influencing both internally and externally? How does the U.S. and ASEAN's cooperation affect the regional security and the development? To answer these questions, the authors will first mention the development history of the ASEAN-U.S. bilateral relations and the cooperation between the two sides in the economic field from the time the two sides started the dialogue partnership from 1977 to 2019. Through evaluating changes in foreign policies between the two in each historical period, especially from 2008 when President Barack Obama came to power, and now President Donald Trump, the paper will analyze in-depth factors affecting economic relations between ASEAN and the U.S., and the impact of this relation to the security situation and the overall economic picture of the region.

\section{Overview of ASEAN - U.S. economic relations}

Since the establishment of dialogue relations in 1977, the ASEAN-US economic cooperation has evolved drastically, witnessing a bunch of turning points in bilateral relations with changes in policies, especially in the post-Cold War period. Early discussions between the 2 sides 


\section{International Journal of Social Science and Economic Research}

ISSN: $2455-8834$

Volume:05, Issue:10 "October 2020"

emphasized primarily on economic issues, encompassing trade, investment, and development. By then, a wider range of cooperative areas have been added for discussions including security, humanitarian assistance, terrorism, etc. Due to changes in international affairs, in Southeast Asia and even in ASEAN itself, the economic collaboration, mainly in trade and investment, between ASEAN and the U.S. has evolved incredibly.

\subsection{From 1977 - end of the Cold War}

During the period from 1977 to the end of the Cold War, ASEAN was still a bloc of 6 countries known as ASEAN-6, therefore in this section, ASEAN is thereby fathomed as the group of 5 founding father economies plus Brunei Darussalam. ASEAN's share of global gross domestic product (GDP) marked at $0.8 \%$ in 1970 , then rose to $1.5 \%$ in 1990 and $2.6 \%$ in 2015 . The U.S., as a dialogue partner with ASEAN in 1977, had GDP of $4.6 \%$ which then decreased sharply to $1.8 \%$ in 1990 and recovered to $2.81 \%$ in 2015, according to the World Bank statistics ${ }^{1}$. Compared to ASEAN's GDP in the same period, it was noted that the growth rate of ASEAN was lower than that of the U.S. all the time. Obviously, the size of the U.S. economy was larger than that of ASEAN, and the U.S. was one of the most important export markets for ASEAN. ASEAN small size was an integral supplier of raw materials for the U.S. market and major recipient of the U.S. investment, bringing mutual benefits to each other.

In 1984, the U.S.-ASEAN Business Council was founded which was the first private-sector-led ASEAN-focused trade association outside of ASEAN. Speaking of the reason this organization was founded then, Feldman - the president of the U.S.-ASEAN Business Council said: "The idea when we were founded in 1984 was that Southeast Asia was going to be important and that it would need a voice to speak for our companies and also to promote opportunities [...]. At that time, China wasn't really a market for us. It wasn't open. Neither was India, so Southeast Asia was the next big thing". As the global economic environment kept changing, for over 10 years, the economic relations between the 2 sides witnessed ups and downs. The trade between ASEAN and the U.S. rose steadily throughout the 1970s and early 1980s before dropping in the second half of the 1980s, affected by global economy and monetary instability due to the 1987 stock market crash and declining oil prices (Seiji, Kernial, Michael \& Narongchai, 1989). The ongoing increase in trade and investment between ASEAN and the U.S. until 1987 is reflected in Table 1.

${ }^{1}$ GDP growth (annual \%). The World Bank. Retrieved from 〈https://data. worldbank.org/indicator/NY.GDP.MKTP.KD.ZG?end=2018\&locations=US\&start=1970〉 (accessed: July 8, 2019) 
International Journal of Social Science and Economic Research

ISSN: 2455-8834

Volume:05, Issue:10 "October 2020"

Table 1: U.S. Investment and Trade with ASEAN (in US\$ millions)

\begin{tabular}{|l|c|c|c|}
\hline & $\mathbf{1 9 8 5}$ & $\mathbf{1 9 8 6}$ & $\mathbf{1 9 8 7}$ \\
\hline Investment & 9,209 & 9,835 & 10,054 \\
\hline Trade $^{2}$ & 23,503 & 23,375 & 27,892 \\
\hline
\end{tabular}

Source: IMF Direction of Trade Statistics Yearbook

Also, ASEAN always received trade incentives from the U.S., reflected in Table 2.

Table 2: U.S-administered trade actions from 1985-1987

\begin{tabular}{|c|c|c|c|c|c|c|c|}
\hline & \multicolumn{4}{|c|}{ Industrial countries } & \multicolumn{3}{|c|}{ Developing countries } \\
\hline Type of investigation & Total & Japan & Canada & Others & $\mathrm{NIEs}^{3}$ & ASEAN & Others \\
\hline \multicolumn{8}{|l|}{ Less than fair value } \\
\hline 1985 & 9 & 2 & 2 & 2 & 1 & 0 & 1 \\
\hline 1986 & 17 & 1 & 3 & 1 & 6 & 0 & 6 \\
\hline 1987 & 37 & 5 & 2 & 14 & 5 & 1 & 10 \\
\hline \multicolumn{8}{|l|}{ Countervailing duty } \\
\hline 1985 & 10 & 0 & 1 & 1 & 0 & 1 & 7 \\
\hline
\end{tabular}

${ }^{2}$ U.S.-ASEAN Import-Export Total.

${ }^{3}$ Newly Industrialized Economies: HongKong, Singapore, Taiwan and South Korea 
International Journal of Social Science and Economic Research

ISSN: 2455-8834

Volume:05, Issue:10 "October 2020"

\begin{tabular}{|l|c|c|c|c|c|c|c|}
\hline 1986 & 5 & 0 & 2 & 1 & 0 & 1 & 1 \\
\hline 1987 & 15 & 0 & 1 & 6 & 2 & 0 & 6 \\
\hline Unfair trading practices & \multicolumn{7}{|l|}{} \\
\hline 1985 & 1 & 0 & 0 & 1 & 0 & 0 & 0 \\
\hline 1986 & 0 & 0 & 0 & 0 & 0 & 0 & 0 \\
\hline 1987 & 1 & 1 & 0 & 0 & 0 & 0 & 0 \\
\hline
\end{tabular}

Source: Modified from DeRosa, 1988 cited from Seiji, Kernial, Michael \& Narongchai, 1989 Compared to other industrial countries belonging to the Newly Industrialized Economies (NIEs), ASEAN has barely been the subject of U.S-administered trade actions. With the signing of the U.S.-ASEAN Business Council, there was a clear framework for operationalizing and enhancing economic cooperation between ASEAN and the U.S. Its impacts were realized in trade, investments, and other preferential policies between the two as shown in Tables $1 \& 2$.

In sum, the U.S. remained an important partner toward ASEAN's economic growth by expanding and diversifying policies and initiatives in economic relations with ASEAN. Consequently, in a decade from 1979 to 1989, ASEAN trade with the U.S. lived in a harmoniously economic cooperative environment rather than confrontational. Statistics generally showed that ASEAN exports to the U.S. increased more than double, from $\$ 7$ billion to $\$ 17.5$ billion, meanwhile, ASEAN imports from the U.S. increased roughly threefold, from $\$ 4$ billion to $\$ 11$ billion ${ }^{4}$.

\subsection{End of the Cold War - 2019}

From 1990 to 1999, ASEAN made an enlargement in the second half of the 1990s. ASEAN economic growth came to reality with the ASEAN Free Trade Area (AFTA) in 1993, opening a new area for economic cooperation between ASEAN with external partners but the U.S. was yet to be one of those. This period of time was considered as a period of "independent and

${ }^{4}$ Ibid. 


\section{International Journal of Social Science and Economic Research}

ISSN: $2455-8834$

Volume:05, Issue:10 "October 2020"

anonymous ASEAN". Over a decade after the Cold War, the U.S. economic policies and priorities seemed to be pivoted to Europe and the Middle East with great economic potential and precious natural resources ( $\mathrm{Ba}, 2009$ cited in Peter \& Micheal, 2014).

From 2000 to 2007, bilateral relations between the U.S. and ASEAN countries were more dominant than relations between the U.S. and ASEAN as a single entity. A bunch of free trade agreements between ASEAN member states such as Viet Nam, Singapore, Thailand, and Malaysia were signed with the U.S. in 2001, 2003, 2003, 2005 respectively. A number of traderelated programs namely Enterprise for ASEAN Initiative (2002), Joint Vision Statement on the ASEAN-U.S. Enhanced Partnership (2005), and TIFA (2006) were proposed and settled. However, these multilateral initiatives had symbolic importance only, having little obvious outcomes to economic collaboration between ASEAN and the U.S.

The period from 2008 to 2019 witnessed major changes in American foreign policy towards Asia. The year 2008 marked the ratification and implementation of the ASEAN Charter - a common framework making changes in the relations among ASEAN member states and ASEAN with external partners. Also, after former U.S. President Obama announced the "Rebalance towards Asia" strategy, showing commitment to deeply engage in Southeast Asia, the ASEANU.S. economic relations boomed incredibly and massively with a host of initiatives and programs launched continuously generating tremendous changes in the bilateral relations. It seems that since 2008, the ASEAN-U.S. relations has been expanded to other sectors with the involvement of many actors such as start-ups, small and medium enterprises (SMEs) both state-owned and private, and so many else. In 2012 in Phnom Penh, Cambodia, the 10 leaders of ASEAN member states along with US President Barack Obama welcomed the launch of "US-ASEAN Expanded Economic Engagement (E3) Initiative". Once established, it is expected to be a new framework for economic collaboration tailored to expand investment and trade between ASEAN and the U.S., as well as laid a foundation for ASEAN countries to prepare high-standards to join regional economic platforms such as the Trans-Pacific Partnership (TPP) at that time.

Roughly one year later, in 2013 U.S.-ASEAN Business Council and the U.S. Agency for International Development (USAID) formed the U.S.-ASEAN Business Alliance for Competitive SMEs. Continuously, a delegation of American chef executives, organized by U.S.ASEAN Business Council, led by U.S. Commerce Secretary Penny Pritzker paid a visit to ASEAN in 2014. The goal of the visit was to express the confidence of the U.S. Business community in the economic development prospect of Southeast Asia and highlighted that the U.S. Commerce "responsible for making all of this region's great opportunities more accessible to American businesses". The number of American companies operating in ASEAN member states increased, with over 4000 companies, located in Singapore with 1836 firms, 795 in 
International Journal of Social Science and Economic Research

ISSN: 2455-8834

Volume:05, Issue:10 "October 2020"

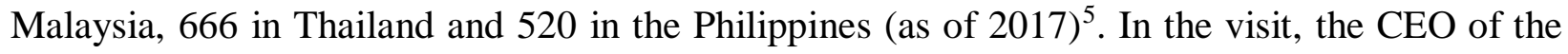
U.S.-ASEAN Business Council when talking about the trade relations between ASEAN and the U.S. said "the advent of AEC really brings together economies of scale that alone none of the 10 ASEAN countries could achieve on their own [...]. ASEAN is incredibly important to the U.S. already, but we see it growing in the future". Impacts of fostering trade, investment and other aspects on ASEAN-U.S. economic relations are shown in Table 3.

Table 3: Two-way trade between ASEAN and the U.S. (US\$ billions)

\begin{tabular}{|l|c|c|c|}
\hline & $\mathbf{2 0 0 8}$ & $\mathbf{2 0 1 7}$ & $\mathbf{2 0 1 8}$ \\
\hline Imports & 61.2 & 78 & 86.2 \\
\hline Exports & 58.5 & 169.8 & 185.8 \\
\hline Trade balance & -2.7 & 91.8 & 99.6 \\
\hline
\end{tabular}

Source: U.S.-ASEAN - 10 Trade and Investment Facts (2019)

Table 3 indicates the effectiveness and significance of ASEAN-U.S. economic cooperation when the trade balance, as well as imports and exports, increased over the years. Compared to 2008 when the U.S. pivoted towards Asia, the 2-way trade balance between the 2 sides has soared dramatically, especially 2-way exports which rose by over US\$ 120 billion after 10 years thanks to strong commitment for economic cooperation between the U.S. government and ASEAN.

${ }^{5}$ ASEAN matters for America /America matters for ASEAN. Retrieved from <https://www.usasean.org/why-asean/investment $>$ (accessed: July $8,2019)$ 
Figure 2: Total value of U.S. - ASEAN bilateral trade (US\$ billions)

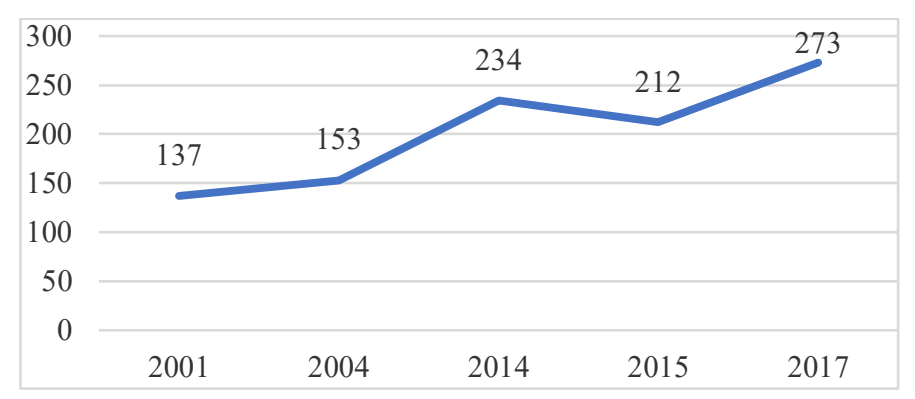

Source: Compiled from East-West Center, ISEAS-Yusof Ishak Institute, US-ASEAN Business Council (2017)

Figure 3: U.S. Direct investment abroad: Direct investment position on a historical-cost basis 2009-2017 (US\$ billions)

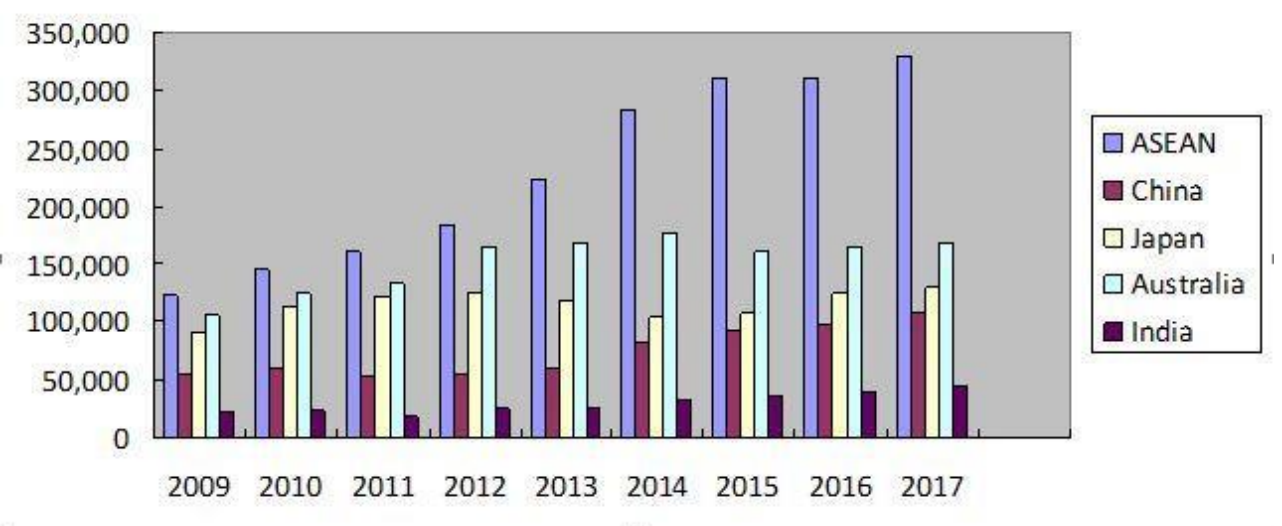

Source: US Bureau of Economic Analysis (BEA), U.S. Department of Commerce

It is obvious from Figure 3 that the U.S. direct investment to ASEAN has seen a steady increase during the analyzed period to date, increased to approximately 3 folds during the 8 years, from US\$ 112,531 billion in 2009 to US\$ 313,638 billion in 2017. Except for Australia, the amount of money pouring into ASEAN since 2013 has always been the combination of that invested in Japan, China and India. ASEAN was ranked the $1^{\text {st }}$ among destinations for U.S. investment in Asia.

\section{Impacts of ASEAN - U.S. economic cooperation}

\subsection{On regional development}




\section{International Journal of Social Science and Economic Research}

ISSN: $2455-8834$

Volume:05, Issue:10 "October 2020"

Firstly, ASEAN currently is regarded as the most potential market for trade enhancement and investment. Being the home to 650 million people with median age around 28 years old, and an economic hub with vigorous economic growth rate, ASEAN is expected to be the world's $5^{\text {th }}$ largest consumer market by 2020 and the $4^{\text {th }}$ biggest economy by 2050 , according to the World Economic Forum report, offering tremendous market opportunities for U.S. enterprises. The U.S. market, in contrast, is an attractive destination for ASEAN-produced goods such as garments, agricultural products and many else. With enormous advantages coming from both potential economies, developing economic ties between ASEAN and the U.S. to be compatible by seizing such potential will strengthen and increase the 2-way turnover remarkably, bringing stability and prosperity to both economies. Moreover, ASEAN market, as just mentioned earlier, plays the crucial and central role in economic calculations of regional giants, therefore, should this market remain stable, so does economic cooperation particularly and regional development generally (WEF, 2016). More importantly, realizing the domination of China-related cooperative and supportive mechanisms and China's ambition to move closer to ASEAN and Southeast Asia through economic cooperation, trade, and investment, the U.S. initiated and proposed a bunch of joint programs. Most notably, the ever first ASEAN-U.S. Summit held in Sunnyland under the leadership of President Obama, then substantially launched US-ASEAN Connect as a strategic framework for better and more realized economic engagement between Washington and ASEAN demonstrated permanent interests of the U.S. toward ASEAN in terms of economics, showing strong commitment to consider ASEAN the most important trading partner in Asia. Those economic programs and initiatives have generated huge impacts on regional development.

Secondly, standing amid the escalating trade war, Southeast Asian countries seem to gain huge profits. Further tariffs are continuously being imposed and manufacturers are shifting out of China due to catastrophic consequences of this years-long friction. ASEAN nations will be the largest beneficiaries as both Chinese and American companies have sharply hastened their investment in Southeast Asia, providing an economic boost to this region. Hence, besides benefiting from the trade war, gaining profits from prosperous ASEAN-U.S. economic relations will contribute significantly to narrowing the development gap among ASEAN countries and these countries with the world's major economies. Positively, the picture of prosperous economic development and cooperation soon reflects the warmth in bilateral and multilateral relations in the region, contributing significantly to ensuring security for regional development.

Thirdly, the U.S.' presence in regional trade relations with ASEAN plays an important role in the region's stability and prosperity. The vibrant economic cooperation between ASEAN and the U.S. also creates attraction, stimulating other countries to participate in the competition if they do not want to be left behind. Economic prosperity is always accompanied by voice and power to influence political issues and foreign policy. Therefore, in order to contribute to promoting the 


\section{International Journal of Social Science and Economic Research}

ISSN: $2455-8834$

Volume:05, Issue:10 "October 2020"

development and prosperity of the region, the ASEAN-U.S. economic cooperation in terms of economic development has promoted the competition and active participation of other countries such as Australia and Japan, creating a more vibrant and colorful regional economic panorama.

However, in addition to promising impacts of ASEAN-US economic relations on regional development, recent calculations of the U.S. are posing tremendous challenges for trade relations between the two sides. Simultaneously, the increasing involvement of many giant economies is also impacting profoundly this relation. The presence and influence of the U.S. in terms of trade in the region and trade relations with ASEAN plays an important role in regional prosperity. The following are factors that affect the stability of ASEAN-U.S. trade relations in the context of a volatile region and why ASEAN and the U.S. should enhance its economic relations to maintain a region with stable development.

Firstly, the increasing presence and deeper engagement of China in Southeast Asia in terms of economics have been reflected through the ratification of ASEAN-China Free Trade Area (ACFTA) which came into effect in 2010, making China the first external party signing FTA with ASEAN, and the establishment of Asia Infrastructure Investment Bank (AIIB) which was officially opened for business in 2016. The ACFTA was signed based on Framework Agreement on Comprehensive Economic Cooperation between ASEAN and China but expanded into all goods, services and investment sectors, enlarging the market size and enhancing two-way trade volume. Since 2009, China has been the ASEAN's top trading partners for 10 years in a row, meanwhile, ASEAN has also become China's third-largest trading partner for 8 consecutive years (Xilian, 2019). After ACFTA came into force, China-ASEAN trade volume increased remarkably as shown in the chart below. 
International Journal of Social Science and Economic Research

ISSN: 2455-8834

Volume:05, Issue:10 "October 2020"

Figure 4: China-ASEAN trade volume in 2011-2017 (US\$ billion)

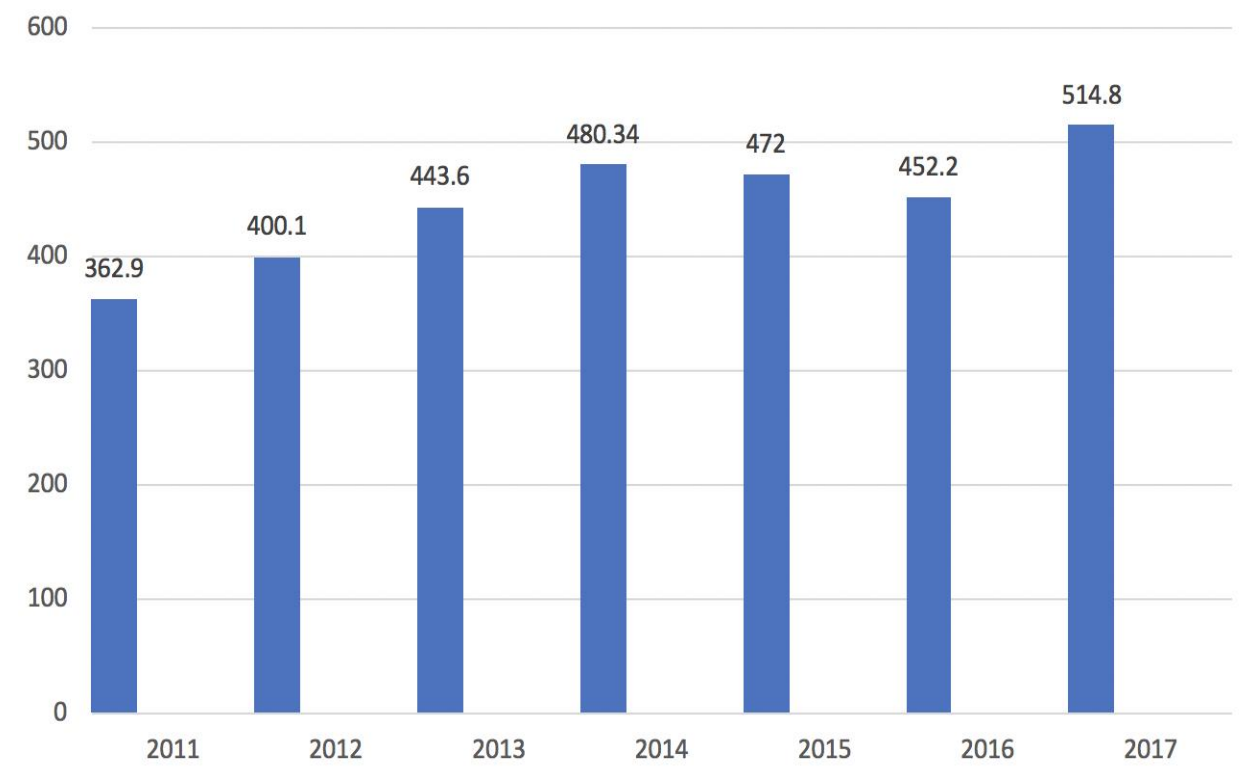

Source: MOFCOM, People.cn, resourced from CGTN, China-ASEAN in numbers: Trade ties ${ }^{6}$.

Figure 4 indicates that regardless of aggressive ambitions, ACFTA truly works for enhancing ASEAN- China economic ties. Also, the launch of AIIB is regarded as a further step broadening and deepening China's footprint in the region; in other words, "the creation of the AIIB reflects China's shifting identity in its relations with ASEAN countries" (Olga \& Serafettin, 2018). With an infrastructure-funding bank of fewer requirements and swift procedures when offering loans and disbursing funds, this China-led initiative approaches Southeast Asian countries as a betteroff and generous but cunning neighbor regardless of the fact that AIIB was established for the entire Asia. China has acknowledged that infrastructure enhancement is crucial for ensuring long-term economic development, and building infrastructure is a must to meet the need for sustainable economic growth. ASEAN countries (except for Singapore), according to an Asian Development Bank (ADB) report, were indicated to expand approximately $\$ 60$ billion per annum (as of 2012) in the next decade to fully deal with infrastructure needs. Financial mechanisms such as ASEAN Infrastructure Fund (AIF) and ADB are unable to accommodate all. Accordingly, AIIB with tremendous financial potential has full ability to fulfill the gap (Olga \& Serafettin, 2018).

Secondly, one of the most notable moves in regional economic affairs is that the U.S. stands outside regional mechanisms such as Comprehensive and Progressive Agreement for Trans-

${ }^{6}$ Retrieved from <https://news.cgtn.com/news/3d3d414e3145544d7a457a6333566d54/share_p.html> (accessed: August 10, 2019) 


\section{International Journal of Social Science and Economic Research}

ISSN: 2455-8834

Volume:05, Issue:10 "October 2020"

Pacific Partnership (CPTPP) ${ }^{7}$ and negotiation process to join Regional Comprehensive Economic Partnership $(\mathrm{RCEP})^{8}$. With controversial views on multilateral cooperation mechanisms to promote trade liberalization and pursuing his own protectionist policies, President Trump has already withdrawn the U.S. out of the TPP, because he supposed that this multilateral cooperation mechanism would hurt the American economy, reducing the profitability of American companies, and losing opportunities of American labors for low-cost workers from developing countries.

On the matter of RCEP, among the Quad countries, Japan plays an incredibly important role in this regional mega-trade pact. Japan has made great efforts to engage India, Australia and New Zealand by facilitating the ASEAN+6 agreement instead of China's ASEAN+3 proposal to eliminate these three countries earlier. As the third largest economy in the world (according to BBC data updated in 2019), Japan is eligible for a leading position in trade diplomacy, and Tokyo also has reliable diplomatic relations with most countries in the Indo-Pacific region, especially with ASEAN and its member states. Considering its ability to handle regional trade issues as of 2019, Japan is the most suitable country. President Trump's trade-restrictive measures have reduced the confidence of partners in the U.S., other countries that support trade liberalization such as Thailand and Australia lack leadership capacity, and China often brings complex issues, even geo-political conflicts, to the negotiating table. Thus, the pursuit of Japan's economic goals will have a great impact on the situation of economic cooperation in the region.

The problem is that over half of ASEAN countries are members of the CPTPP and RCEP. Therefore, in order not to lose good relations with ASEAN and dynamic economies in Southeast Asia as well as to make the most of potential from the AEC, the U.S. has to endure the partnership with ASEAN and its member countries, especially with its allies Thailand and the Philippines, and CLMV countries ${ }^{9}$ via Low-Mekong Initiative, ASEAN Single Window, Overseas Private Investment Corporation, and so many else. Understandably, although the U.S. has no presence and any voice in such regional economic mechanisms of CPTPP or upcoming RCEP, it still remains cherished relations economically with ASEAN and ASEAN states because ASEAN's dynamic economies and high growth rates make it a key market for American exports and investment. More importantly, having no presence in CPTPP forces the U.S. to pay special attention to ASEAN economies and AEC. This means that the U.S. could maintain its position not to lose its commercial influence in the region. Moreover, the withdrawal of the U.S. from the TPP allowed China to expand trade and economic development in Southeast Asia. Therefore,

${ }^{7}$ CPTPP is a free trade agreement formed after the withdrawal of the U.S. from TPP. This agreement includes Canada and 10 other countries in the Asia-Pacific region, namely: Chile, Australia, New Zealand, Peru, Singapore, Vietnam, Brunei, Malaysia, Mexico, and Australia.

${ }^{8}$ Regional Comprehensive Economic Partnership, including 10 ASEAN Member States and 6 ASEAN's external partners: Australia, Chi na, India, New Zealand, South Korea, and Japan.

${ }^{9}$ CLMV includes Cambodia, Laos, Myanmar and Viet Nam. 


\section{International Journal of Social Science and Economic Research}

ISSN: 2455-8834

Volume:05, Issue:10 "October 2020"

this permanent presence and influence of the U.S. economically with AEC and ASEAN countries play a role in curbing China's development and its assertive actions.

Thirdly, the US-China trade war started in 2018 and is escalating alarmingly, affecting enormously to not only two main players - China and the U.S. but other countries as well. Southeast Asia and ASEAN are always an attractive area among powers. Both the U.S. and China are the largest trading partners of Southeast Asian nations. China is ASEAN's largest single trading partner, while the US is an important strategic and economic partner with growth and spending having a significant impact on boosting trade worldwide. As the war continues to prolong, it will greatly affect exports from ASEAN countries to these countries as the trade war slows growth in both markets. Even worse, the International Monetary Fund (IMF) has warned that a comprehensive trade war will weaken the global economy. Additionally, another trade war is also erupting in Northeast Asia between Korea and Japan when economic struggles are escalating between the two countries. The Japan-Korea trade tensions broke out in the context of a continued trade war between China and the U.S., prompting economists to ring a warning bell about disruptions in technology supply chains and its subsequent negative impacts on the global economy.

However, stemming from their geographical position, strong supply chain and global distribution network, the large workforce with low labor costs and good relations with superpowers, ASEAN countries will become alternative manufacturing bases to China. Trade war will make ASEAN nations an alternative for textile, footwear, and metal processing companies from the U.S., Japan, and Korea to shift their investment, instead of continuing to place factories in China, thus entailing trade and investment shifts in a way that benefits ASEAN. In contrast, with tariffs on export goods keep increasing, Southeast Asian goods are now more attractive to American consumers, and the economic and trade relations between ASEAN and the U.S. continues to stand firmly in the context of a volatile region. "In the long term, we [the U.S.] are pretty confident that ASEAN is a very attractive alternative to the supply chain for companies looking to diversify away from China" - Satish Shankar, managing partner for Southeast Asia.

One more direct consequence of the trade war is that many countries are adjusting their local currency prices to save growth and exports and to cope with competitive disadvantages simultaneously. The currency prices of Southeast Asian countries such as the Philippines or Indonesia all have dropped sharply. The yuan value has dropped incredibly within 11 years, since the 2008 crisis. The devaluation of the yuan also means that many Chinese goods will be cheaper than ever. This would be beneficial for ASEAN countries' domestic businesses when they may spend less money to purchase raw materials from China. Therefore, in the context of economic and monetary tension of major economies in the world experiencing great fluctuations, 


\section{International Journal of Social Science and Economic Research}

ISSN: $2455-8834$

Volume:05, Issue:10 "October 2020"

if Southeast Asian countries depend entirely on the Chinese export market, it will be very difficult for export because product value will be higher than the Chinese domestically produced goods.

Consequently, in the long run, if the trade war continues, maintaining close economic cooperation with the U.S. will generate favorable conditions for ASEAN countries to acquire advantages in exports and maintain trade steadily. At the same time, increasing the two-way trade turnover of ASEAN-US requires ASEAN's goods to meet international standards and American standards. ASEAN will be a beneficiary and the development gap among ASEAN countries and with economic superpowers will be narrowed, thereby making Southeast Asia a region of prosperity and an economic hub in Asia and asserting its eco-political position in this area. Simultaneously, the sustainability of ASEAN - U.S. economic relations is decisive for regional development in the context that the two largest economies are competing.

\subsection{On regional security}

The American commitment to Southeast Asia has tremendous impacts on regional security. The Obama administration previously showed a strong position to pivot to Asia and strengthen its presence in the region to curb other countries intending to monopolize this geostrategic region. However, the Trump administration shows inconsistency in his foreign policy towards this region. This paved the way for great powers, particularly China and countries in the Quad group, to have stronger impacts on the regional foreign policy.

Firstly, Southeast Asia is the premier gateway for international trade on both land and seas, connecting Asia and the world, and the South China Sea (SCS) is a life-line, with about 50\% of goods in the world passing through this area. Therefore, any conflicts and uncertainties in this area are not welcomed by both the U.S. and ASEAN. China, in addition to promoting its involvement and increasing its influence on the mainland, also has aggressive and provocative actions to assert its legal sovereignty. Simultaneously, China increases control over the SCS, causing various concerns for countries within and outside the region. In recent years, China has continuously taken actions causing grievances in the international community such as the construction of man-made islands, military bases on the Spratly and Paracel Islands; unilaterally imposing fishing ban on the SCS in high season, and bringing Haiyang 981 drilling rig to the waters of Viet Nam's exclusive economic zone. All those actions aim to create logistics facilities for fisheries and oil and gas activities in the SCS, expand the scope of fishing, exploit marine resources, in addition to military and political intrigues.

For the U.S., ASEAN is an extremely important trading partner, and transport routes across the SCS are the life-line of the U.S. economy with Southeast Asia and East Asia, and a crucial route 


\section{International Journal of Social Science and Economic Research}

ISSN: $2455-8834$

Volume:05, Issue:10 "October 2020"

for American vessels from the West Coast to reach the Indian Ocean and Persian Gulf (Taylor, 2014). After the illegal activities that China conducted in the SCS with a desire to dominate the region economically, U.S. congressmen were concerned about Beijing's rapid militarization in the SCS, fearing consequences for other countries in the world if China blocks this important shipping route. Because of that, the U.S. has formed a group of congressmen in charge of Southeast Asian affairs, led by Joaquin Castro - representative from Texas and Ann Wagner representative from Missouri to affirm U.S. permanent concern for trade and economic relations with ASEAN. In an interview with the Strait Times in the Washington office, Mr. Castro said: "China really has stepped up its activities in Southeast Asia, trying to dominate the region economically" (Ghosh, 2018). ASEAN Caucus is also the adjustment of the U.S. to ASEAN after the Trump government withdrew from TPP, "That's why we are making an extra effort to let them (ASEAN) know we want to continue to increase trade, to continue to have deeper relations" 10 .

Secondly, India immediately upgraded its "Look East" policy to "Act East" policy which is actions and outcome-oriented after Prime Minister (PM) Modi came to power in 2014. In this sense, Southeast Asia is considered to be an important player in New Delhi's eastbound plan. ASEAN is a cooperative organization located in an area of important geopolitical status for India in the integration of East Asia and the Asia-Pacific region. ASEAN is also the driving force in multilateral cooperation structures in the region that are highly regarded by India such as East Asia Summit and Asian Regional Forum. Therefore, India is making efforts to increase its presence in Southeast Asia through oil and gas exploitation projects, telecommunications, services, software, finance and banking, infrastructure development, and looking for opportunities to enhance India's influence in the region.

Recognizing the immense criticality of effective economic integration via economic corridors, India and ASEAN countries have established cutting-edge transport infrastructure to enhance economic growth by linking economies, and most importantly, serving as a counterweight of China's Belt and Road Initiative (BRI). India - Myanmar - Thailand trilateral highway would be a promising project which might benefit immensely the regions around the Bay of Bengal and creates a development corridor to connect India and other ASEAN countries besides Myanmar and Thailand (Roshan, 2017), and has been recommended to extend to Laos, Cambodia and Viet Nam soon. Another on-going project is Kaladan Multi-Modal Transit Transport Project connecting Indian northeastern states and Southeast Asia through Myanmar. This is a transit route comprising several modes of transportation of segments including shipping from Kolkata to Sittwe, Inland Water Transport from Sittwe to Paletwa, and Road from Paletwa to Indo-

${ }^{10}$ Ibid. 


\section{International Journal of Social Science and Economic Research}

ISSN: $2455-8834$

Volume:05, Issue:10 "October 2020"

Myanmar border-NH54 ${ }^{11}$. According to an analysis on the Hindu BusinessLine, this project economically is boosting the economy of Myanmar while geo-strategically, this project would be an alternative route for commodities going from India's northeast states to Myanmar to balance China's growing influence in Myanmar and Southeast Asia as a whole.

Thirdly, ASEAN and the Indo-Pacific region truly matters to Canberra and Tokyo, similar to ASEAN's role in relations with India. Japanese PM Shinzo Abe in the meeting with Malaysian PM Mahathir Mohamad in 2018 decided to soften tone on Indo-Pacific "to coax China's ASEAN friends" by changing FOIP geo-strategically regional initiative into "vision" after Japan realized the word "strategy" had raised some concerns to ASEAN"12. To Tokyo, the concept of this vision was to promote shared values of rules-based order and free-market economies. Besides the domination of the economic realm, security in reality with ASEAN has long been the major area of Tokyo's interest. Having been incorporated into Japan's FOIP vision, Japan-ASEAN Ship Rider Program under Vientiane Vision announced in 2016 by Tokyo has functioned as Tokyo's efforts to expand and accelerate its security role with ASEAN. Primary objective of this annual spotlight defense cooperation program since the first launch in 2017 is to promote capacitybuilding for ASEAN countries in many areas, including international maritime law, humanitarian assistance and disaster relief. Generally, Tokyo has expressed its determination in the economic domain in Indo-Pacific which contributes to both the dynamic and competition in the region.

To Australia, the U.S. and China have been Canberra's years-long partners in a myriad of aspects, ranging from defense to economic cooperation. However, the cooperation with Washington has not seen any new initiatives announced since the Trump administration came into office. Meanwhile, Canberra's relationship with Beijing is becoming worse and worse over matters such as interference into domestic affairs, China's acceleration of investment in infrastructure which has caused difficulties for Canberra to keep its diplomatic ties with Beijing normal. Uncertainties exist among the trilateral relations of Australia - the U.S. - China along with the U.S.-China deteriorating relationship since 2018 after tit-for-tat tariff imposition. Amidst such challenges, Australia is seeking cooperation and expanding its diplomacy towards Indo-Pacific region, and ASEAN is placed in its heart. The latest move was shown in the ASEAN-Australia Special Summit in Sydney in March 2018, when the 2 parties agreed to set up ASEAN-initiated high-quality regional infrastructure pipeline, unlocking economic potentials between the 2 sides, and restraining the rising Chinese influence through BRI simultaneously.

${ }^{11}$ Ministry of Development of North Eastern Region. Retrieved from < $\underline{\text { https://mdoner.gov.in/infrastructure/kaladan-multi-modal-transit- }}$ transport-project-inland> (accessed: August 13, 2019)

${ }_{12}$ PM Abe Shinzo first referred to the concept of Indo-Pacific in 2016 in a convention in Nairobi, Kenya. This concept later was used as Japan's FOIP strategy but changed into vision in 2018 when used with ASEAN 


\section{International Journal of Social Science and Economic Research}

ISSN: $2455-8834$

Volume:05, Issue:10 "October 2020"

In conclusion, the economic competition to get deeper presence and influence among superpowers with ASEAN are happening in both Southeast Asian mainland and on the sea. In land, when two giant economies China and India have shown distinct attention to this region. Beijing is increasingly using economic coercion to put U.S. allies and partners in Southeast Asia under pressure. New Delhi is also hurriedly showing its aims to get closer with ASEAN through trade and massive investment to emphasize their interest and commitment to be a strategic partner with ASEAN and ASEAN countries. Tokyo and Canberra are also engaging actively with ASEAN to lift their political position up in regional affairs through strengthening infrastructure investment and defense cooperation as aforementioned. Therefore, the U.S. encourages the strengthening of economic commitments with ASEAN through the elimination of trade barriers, the establishment of specialized bodies for ASEAN affairs in the region, and the tightening of economic relations with ASEAN. This means avoiding regional problems to impose negative impacts on the intimate economic ASEAN-U.S. relations, and at the same time, making the economy a tool in controlling regional security, preventing a great power from being hedged in the region against the context of U.S. political power decrease.

On the sea, the growing importance of the SCS to regional and world trade is undeniable. Therefore, the U.S. has increased economic and trade relations and cooperation in oil and gas exploitation with the dispute claimant countries. At present, almost all of American oil companies have signed an oil exploitation agreement with all claimants over the SCS disputes, thus gaining huge profits. Particularly, ExxonMobil Petroleum Corporation signed a framework agreement for the development and selling gas to PetroVietnam. The U.S. wants to strengthen economic, trade and energy relations with ASEAN countries to strengthen its influence on these countries by joining the oil and gas group of Southeast Asian countries to exploit oil in the SCS. After all, the U.S. increased its economic and trade ties and involvement in the SCS to curb China's rise. Besides, American goods imported into Southeast Asia and East Asia through the SCS are increasing. Thus, strengthening economic cooperation with ASEAN countries through sea lanes means maintaining the peaceful and sustained environment, preventing any country from rising to challenge the U.S. leadership position, control the region, threaten the security of the U.S. and its allies and change the rules that are being shaped to be beneficial for the U.S., maintaining and enhancing the prosperity of the world's number one economy.

\section{Outlook for ASEAN - U.S. economic cooperation and policy implications}

\subsection{Outlook for ASEAN - U.S. economic cooperation}

The ASEAN-U.S. relations have been facing myriads of emergent challenges and changes lately, especially when President Trump decided to skip the EAS and U.S.-ASEAN summit in 


\section{International Journal of Social Science and Economic Research}

ISSN: $2455-8834$

Volume:05, Issue:10 "October 2020"

Singapore in 2018, and not inviting any Southeast Asian leaders. The U.S. is no longer a member of the discussion table of regional economic cooperation mechanisms such as CPTPP and upcoming RCEP, the trade war between the U.S. and China is yet to see any signal of coming to a stop and the presence of two giant economies China and India has had certain impacts on pushing closer ASEAN-US relations. All these factors have fostered ASEAN - U.S. economic relations closer, anticipating the ties to be warmer in the upcoming time. On the U.S.'s side, ASEAN still holds the position of an important trading partner of this country. With the advantage of the world's third-largest labor workforce with a young population, and is also a potential production base when businesses are moving factories to Southeast Asia to deal with trade wars, ASEAN possibly ensures to maintain competitiveness on both physical and digital economy in the future. On the ASEAN's side, the U.S. is a key investor in this region.

In the context of the devaluation of the yuan due to the trade war, the dollar retains the value of a means of transaction and international reserves, which has a significant impact on trade and investment flows from ASEAN countries, and the U.S. will be the market for export products from ASEAN. Especially the traditional products which were China's strengths for the US market including electronic components, high-tech goods, and household appliances will be shortly replaced by those manufactured in Southeast Asia. ASEAN countries will be an alternative for China to enter the supply chain system which furnishes goods to the U.S. market. However, it is necessary for the suppliers and distributors in ASEAN to improve their standards and quality to meet strict requirements and standards of importing goods into the U.S. Thereby, the quality and standards of ASEAN's SMEs will be improved, while changing positively the U.S. companies' perspective on ASEAN market. Correspondingly, the cooperation between ASEAN and the U.S., in the long run, will be strengthened at both micro and macro levels.

\subsection{Policy implications}

In the context of a region with such unanticipatedly volatile affairs, ASEAN and the U.S. have to strive effort fully to maintain and strengthen their economic ties which play a crucial role in boldly emphasizing the position of both sides politically as stated earlier in this paper. The two sides still need to keep striving hard to avoid negative impacts from external challenges as well as boost positive impacts on regional security and development.

Firstly, as the U.S. already pulled itself out of TPP and showed no interest in RCEP, this opens room for greater Chinese influence and impacts from the Quad countries down to earth, and for some ASEAN member states to increase their economic engagement with China accordingly. Therefore, to make such a tight concatenation with ASEAN countries and not damage regional economic security, the U.S. should continue to promote comprehensive cooperation with 


\section{International Journal of Social Science and Economic Research}

ISSN: $2455-8834$

Volume:05, Issue:10 "October 2020"

ASEAN and bilateral cooperation with ASEAN through its Action Plans to support ASEAN countries in capacity building to respond to regional and global challenges. Simultaneously, the Trump administration needs to construct a strategic and committed economic relations with ASEAN which builds trust and makes ASEAN and ASEAN Member States believe in a prosperous future against the context of the regional security and development being affected profoundly by impacts from inner and outer-region countries and interest groups.

Secondly, employing alternative channels to make a stronger ASEAN-U.S. economic relation. Instead of utilizing government-to-government track, cooperation through existing bilateral programs and initiatives should be leveraged and reaffirmed. Cases in point, platforms such as U.S.-ASEAN Connect Initiative, ASEAN Single Window, and E3 Initiative, serving as either track 1.5 or track 2 which brings all together state-owned enterprises and private ones, should be further enhanced to optimize their purposes and potential in connecting and reinforcing ASEAN and the U.S. economic partnership.

Thirdly, ASEAN enterprises and businesses should focus on advancing technical, vocational and intellectual skills and brain for the young and plentiful labor force in the region. The transformation of the economic model towards the development of manufacturing industries with advanced science and technology, promoting entrepreneurship and creativity is extremely practical and necessary. Possessing a resourceful and well-trained workforce with practical skills will definitely generate long-term results which significantly contribute to manufacturing highquality products, meeting international standards and the U.S. market's demands. Additionally, those firms should also improve competitiveness, identify a reasonable product structure as well as improve regional-manufactured goods standard, aiming at increasing and balancing two-way export turnover, moving towards a cooperative bilateral relation which is commercially equal. As a leading partner of ASEAN, with strengths in science, technology, innovation, production systems, global business networks, the U.S. needs to strengthen cooperation, support ASEAN in building community, develop small and medium enterprises, digital economy, high technology, clean energy, promote entrepreneurship, entrepreneurship and creativity.

Lastly, the role of ASEAN centrality in regional multilateral forums and mechanisms such as East Asia Summit and Asian Regional Forum, and the latest Indo-Pacific concept has increasingly become crucial. Therefore, ASEAN needs to balance economic relations with regional powers besides the U.S. such as China, India, Japan, Australia and South Korea skillfully, avoiding the dilemma of completely leaning on one side and the "trap" fabricated by such powerful economies. As such, ASEAN should strengthen their commitment to multilateralism, welcoming all economic cooperation initiatives proposed by any powers as long 
International Journal of Social Science and Economic Research

ISSN: 2455-8834

Volume:05, Issue:10 "October 2020"

as it is open, rules-based, transparent and beneficial for regional prosperity to ensure security and regional development.

\section{References}

ADB. (2012). Facts and Data about ASEAN Infrastructure. Retrieved from Asian Development Bank: https://www.adb.org/features/fast-facts-asean-infrastructure-fund

ASEAN. (2017). A journey towards regional economic integration. Jakarta: ASEAN Secretariat.

ASEAN. (2017). ASEAN Investment Report 2017 - Foreign Direct Investment and Economic Zones in ASEAN. Jakarta: ASEAN Secretariat.

ASEAN. (2018). ASEAN Key Figures 2018. Jakarta: ASEAN Secretariat.

Ba, A. D. (2003). China and ASEAN: Renavigating Relations for a 21st-Century Asia. Asian Survey, 43(4), 622-647.

Calaguina-Cruz, M. (2011). Development in ASEAN-U.S. Relations. In P. Chachavalpongpun, ASEAN-U.S. Relations: What are the talking points? (pp. 10-16). ISEAS - Yusof Ishak Institute.

CGTN. (2018). China-ASEAN in numbers: Trade ties. Retrieved from CGTN: https://news.cgtn.com/news/3d3d414e3145544d7a457a6333566d54/share_p.html

David, W. (2018). How to keep the ASEAN economies growing for another 50 years. Retrieved from World Economic Forum: https://www.weforum.org/agenda/2018/09/to-keepgrowing-aseans-economy-must-adapt-heres-how/

DeRosa, D. (1986). ASEAN - U.S. Trade Relations: An Overview. ASEAN Economic Bulletin, 3(2), 169-188. Retrieved from ASEAN Economic Bulletin.

East-West Centre, US-ASEAN Business Council, \& ISEAS-Yusof Ishak Institute. (2017). ASEAN matters for America - America matters for ASEAN.

Ghosh, N. (2018). Concerned about China's influence, Congressional ASEAN group wants deeper US-ASEAN ties. Retrieved from The Straits Times:

https://www.straitstimes.com/world/united-states/concerned-about-chinas-influencecongressional-asean-group-wants-deeper-us-asean 


\section{International Journal of Social Science and Economic Research}

ISSN: $2455-8834$

Volume:05, Issue:10 "October 2020"

Hans, I. H., \& Patrick, M. M. (1989). Linkage or Bondage: U.S. Economic Relations with the ASEAN Region. GreenWood Press.

Kaewkamol, P. K. (2018). The 32nd ASEAN Summit's Economic Priorities and Implications for US-ASEAN Economic Relations. Asia Pacific Bulletin, 422.

Marciel, S. (2009). A new era in the long-standing U.S.-ASEAN relationship. In P. Chachavalpongpun, ASEAN - U.S. relations: What are the talking points? (pp. 27-38). ISEAS - Institute of Southeast Asian Studies.

Michael, P. G. (2017). US-ASEAN Relations in a changing global context. ASEAN at 50: A Look at its external relations, pp. 139-151.

Olga, D., \& Serafettin, Y. (2018). The AIIB and China-ASEAN Relations: Shaping a New North-South Paradigm. China Quarterly of International Strategic Studies, 4(1), 95-121.

Peter, P. A., \& Michael, P. G. (2014). ASEAN Centrality and the ASEAN-US Economic Relationship. Honolulu: East-West Center.

Rahman, H. (2015). China ASEAN Economic Relations and USA Factor. International Journal of Scientific Research in Science and Technology, 1(4), 286-298.

Roshan, I. (2017). A Promising Trilateral: india - Myanmar - Thailand. Retrieved from The Diplomat: https://thediplomat.com/2017/09/a-promising-trilateral-india-myanmarthailand/

Seiji, N., Kernial, S. S., Michael , P., \& Narongchai, A. (1989). ASEAN-U.S. Initiative: Assessment and Recommendations for Improved Economic Relations: Joint Final Report. East-West Center, ISEAS-Institute of Southeast Asia Studies.

Taylor, F. M. (2014). Policy Report: U.S. Policy Towards the Disputes in the South China Sea Since 1995. S.Rajaratnam School of International Studies.

Terence, C. (2017, 8). The Politics behind Cambodia's Embrace of China. ISEAS Perspective (59).

U.S.-ASEAN - 10 Trade and Investment Facts. $(2019,4)$. Retrieved from Office of the United States Trade Representative - Executive Office of the President: https://ustr.gov/issueareas/trade-organizations/association-southeast-asian-nations-asean/us-asean-10-tradeand 
International Journal of Social Science and Economic Research

ISSN: 2455-8834

Volume:05, Issue:10 "October 2020"

WEF. (2016). World Economic Forum on ASEAN: Shaping the ASEAN Agenda for Inclusion and Growth. World Economic Forum.

Xilian, H. (2019). China and ASEAN doing well on economic trade cooperation. Retrieved from The Jakarta Post: https://www.thejakartapost.com/academia/2019/01/31/china-and-aseandoing-well-on-economic-trade-cooperation.html 